\title{
Commercial Buildings Energy Consumption Survey (CBECS) and Its Comparison with Turkey Applications
}

\author{
Ö. Boydak
}

\begin{abstract}
This paper is about commercial buildings energy consumption survey (CBECS) benchmarking database consept, its applications and related applications in Turkey. CBECS is useful for energy efficiency in new commercial building constructions, which is a key target to control and lower U.S. nation-wide energy use.

Determining energy consumption of buildings is a key target for energy efficiency. Building energy efficiency is crucial especially for economical and climate change concerns. Improving energy efficiency in commercial buildings is useful in order to decrease energy use, owner operating costs, and carbon footprint of the buildings.

The aims are to estimate life-cycle energy savings, cost performance of energy efficiency and carbon emission reduction in new commercial buildings utilizing an integrated design, and estimate results. Obtaining energy consumption of buildings can be utilized to decrease energy usage in new commercial buildings by $20-30 \%$ on average and up to over $40 \%$. Thus, improved efficiencies permit smaller, cheaper HVAC equipment usage.
\end{abstract}

Index Terms-Energy, renewable energy, energy consumption, CBECS, energy saving.

\section{INTRODUCTION}

Building energy efficiency has come to the forefront of political debates due to high energy prices and climate change concerns. Improving energy efficiency in new commercial buildings is one of the easiest and lowest cost options to decrease a building's energy use, owner operating costs, and carbon footprint [1].

Office buildings must be improved to make major gains in reducing U.S. building energy use. Energy benchmarking offers initial building energy performance assessment without rigorous evaluation. "Seeing" that building energy use is excessive, is the first step to change. Energy benchmarks based on the Commercial Buildings Energy Consumption Survey (CBECS) are investigated in support of the U.S. Department of Energy's Energy Partnerships program [2].

\section{CBECS DATA}

CBECS stands for "Commercial Buildings Energy Consumption Survey". CBECS database compiled by the U.S Department of Energy: "CBECS is a national sample survey that collects information on the stock of U.S. commercial

Manuscript received August 14, 2015; revised December 23, 2015. This work was supported in part by Marmara University.

Ö. Boydak is with the Mechanical Engineering Department, Istanbul Medeniyet University, Unalan, 34700 Istanbul, Turkey (e-mail: ozlem.boydak@medeniyet.edu.tr). buildings, their energy-related building characteristics, and their energy consumption and expenditures" [3].

Sample sizes ranges from 5,000 to 7,000 buildings nationwide. Confidentiality, all data are collected under the Confidential Information Protection and Statistical Efficiency Act of 2002 (CIPSEA). CBECS interviews conducted professionally using a computerized survey instrument and usually lasts 30 minutes [4].

Advance package of materials (including worksheets) are provided to building a few days before interview. They cover many topics - building size and use, ownership and occupancy, energy sources, uses, equipment, energy consumption and cost. CBECS interviews are followed by an energy supplier survey - if useable energy usage information is not available from building respondent [5].

\section{CBECS BUILDINGS}

In the Commercial Buildings Energy Consumption Survey (CBECS), buildings are classified according to principal activity, which is the primary business, commerce, or function carried on within each building. Commercial buildings include all buildings in which at least half of the floorspace is used for a purpose that is not residential, industrial, or agricultural, so they include building types that might not traditionally be considered "commercial" such as schools, correctional institutions, and buildings used for religious worship [6].

Target population of CBECS interviews are any building that is not residential, not agricultural, and not manufacturing The excluded buildings from CBECS are buildings less than 1,000 square feet, parking garages, buildings on military bases, other restricted-access buildings, and buildings on manufacturing facilities [7].

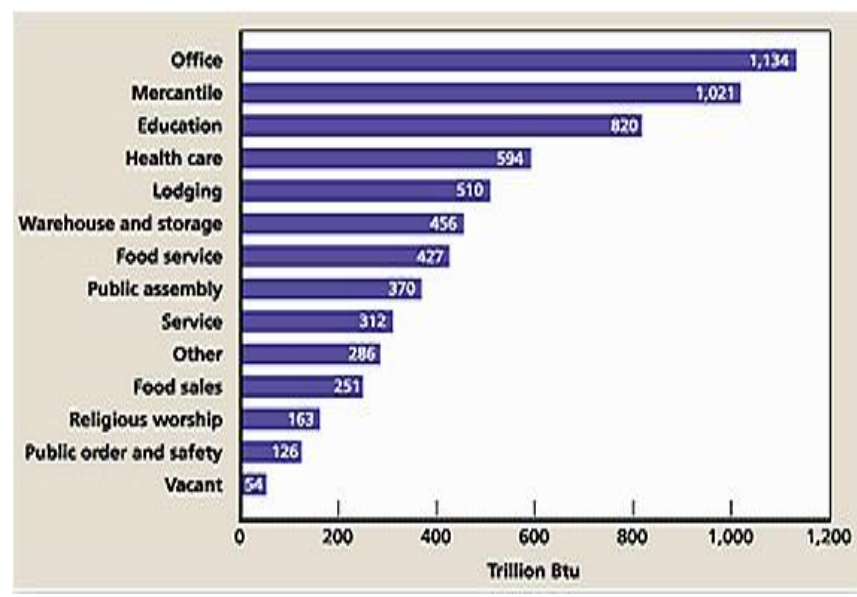

Fig. 1. CBECS data of year 2003 for energy consuming rates of each type of U.S. commercial buildings [4] 
Anyone can download the CBECS database files from the U.S. Department of Energy, but the raw data is not easily used. BuildingBenchmarks.com is a user-friendly website that simplifies the data and displays it immediately. CBECS is public domain data. As an example, CBECS data of year 2003 for energy consuming rates of each type of U.S. commercial buildings can be observed in the Fig. 1 [4].

\section{CBECS DATA RESUlTS}

Key milestones for CBECS can be seen in the Fig. 2. These key milestones are the important steps for taking the CBECS data results [8].

TABLE I: 2003 CBECS NATIONAL MEDIAN SOURCE ENERGY USE AND PERFORMANCE COMPARISONS BY BUILDING TYPES [9]

\begin{tabular}{|c|c|c|c|}
\hline Building Use Description & $\begin{array}{c}\text { Average } \\
\text { Source EUI } \\
\text { (kbtu/Sqft) }\end{array}$ & $\begin{array}{l}\text { Average } \\
\text { Percent } \\
\text { Electric }\end{array}$ & $\begin{array}{c}\text { Average } \\
\text { Site EUI } \\
(\mathbf{k b t u} / \mathrm{SqFt})\end{array}$ \\
\hline Education & 170 & $63 \%$ & 76 \\
\hline $\begin{array}{l}\text { College/University } \\
\text { (Campus-level) }\end{array}$ & 280 & $63 \%$ & 120 \\
\hline Food Sales & 681 & $86 \%$ & 225 \\
\hline $\begin{array}{l}\text { Convenience Store (with } \\
\text { or without Gas Station) }\end{array}$ & 753 & $90 \%$ & 241 \\
\hline Food Service & 786 & $59 \%$ & 351 \\
\hline Restaurant/Cafeteria & 612 & $53 \%$ & 302 \\
\hline Fast Food & 1306 & $64 \%$ & 534 \\
\hline Health Care: Outpatient & 183 & $72 \%$ & 73 \\
\hline $\begin{array}{c}\text { Clinic/Other Outpatient } \\
\text { Health }\end{array}$ & 219 & $76 \%$ & 84 \\
\hline Lodging & 194 & $61 \%$ & 87 \\
\hline $\begin{array}{l}\text { Mall (Strip Mall and } \\
\text { Enclosed) }\end{array}$ & 271 & $71 \%$ & 107 \\
\hline Public Assembly & 143 & $57 \%$ & 66 \\
\hline Entertainment/Culture & 265 & $63 \%$ & 95 \\
\hline Library & 246 & $59 \%$ & 104 \\
\hline Recreation & 136 & $55 \%$ & 65 \\
\hline Social/Meeting & 102 & $57 \%$ & 52 \\
\hline Public Order and Safety & 189 & $57 \%$ & 90 \\
\hline Fire Station/Police Station & 157 & $56 \%$ & 78 \\
\hline Service (Vehicle/Postal) & 150 & $63 \%$ & 77 \\
\hline $\begin{array}{l}\text { Storage/Shipping/Nonrefri } \\
\text { gerated Warehouse }\end{array}$ & 56 & $56 \%$ & 25 \\
\hline Self-storage & 12 & $44 \%$ & 4 \\
\hline $\begin{array}{l}\text { Distribution/Shipping } \\
\text { Center }\end{array}$ & 90 & $61 \%$ & 44 \\
\hline Religious Worship & 83 & $52 \%$ & 46 \\
\hline Other & 213 & $56 \%$ & 104 \\
\hline
\end{tabular}

From Table I, 2003 CBECS national median source energy use and performance comparisons by building types can be observed [9].

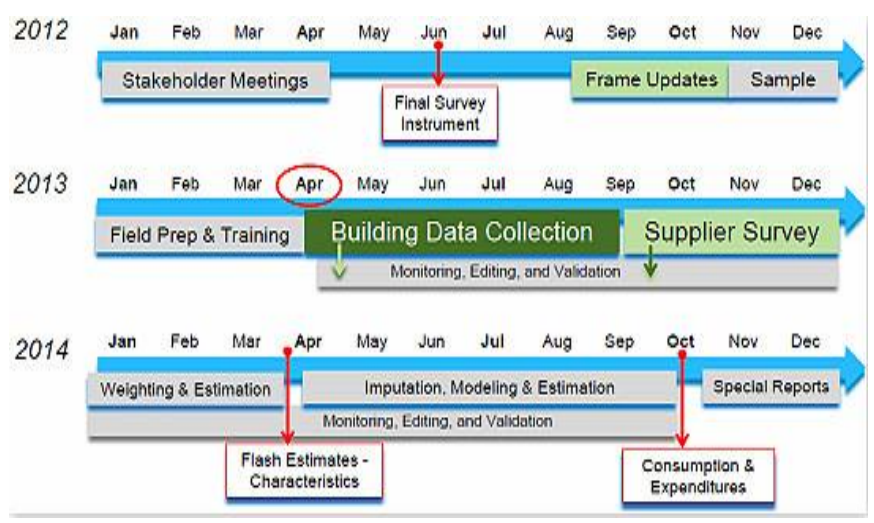

Fig. 2. Key milestones of CBECS [8].

\section{ADVANTAGES OF CBECS}

CBECS data is valuable. CBECS creates a "benchmark" by displaying the energy use of a typical building of your type and location. Use this valuable "peer group" information to help answer questions such as [10]:

Is the building relatively efficient or inefficient compared with its peer group?

When a building is built or bought, what can be expected the annual energy usage to be?

What is the estimated operational breakdown of building energy usage?

How does energy usage vary in different parts of the country?

Should energy management projects in the building be invested?

Additionally, commercial buildings energy intensity over time can be learned by CBECS data results as seen in Fig. 3 [11].

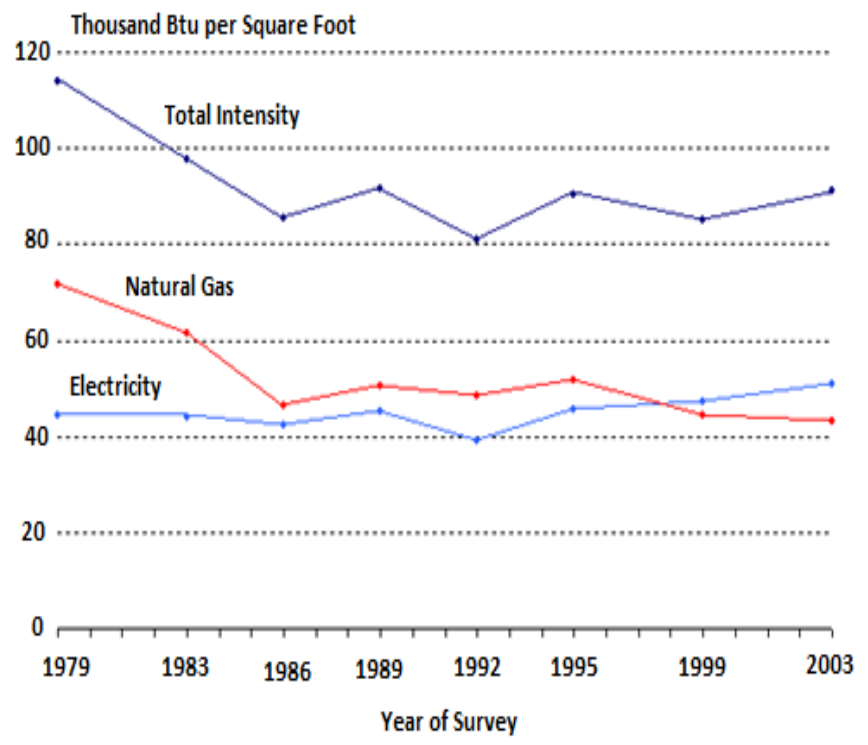

Fig. 3. Commercial buildings energy intensity over time [11].

Energy Star is an international standard for energy efficient consumer products originated in the USA. It was created in 1992 by Environmental Protection Agency (EPA) and the Department of Energy (DOE). Since then, Australia, Canada, Japan, New Zealand, Taiwan and the European Union have adopted the program [12]. 
CBECS is not same as ENERGY STAR, but they are related. The statistical engine that creates ENERGY STAR building ratings uses CBECS as the foundation. EPA conducts statistical analysis on the data gathered by the Department of Energy's Energy Information Administration during its quadrennial CBECS.

Baseline is another surveying like CBECS in USA. A baseline survey is one that looks at study characteristics at a particular time or under a particular set of conditions to establish a "base line". Compared values of Baseline and CBECS are seen in the Fig. 4 [13], [14].

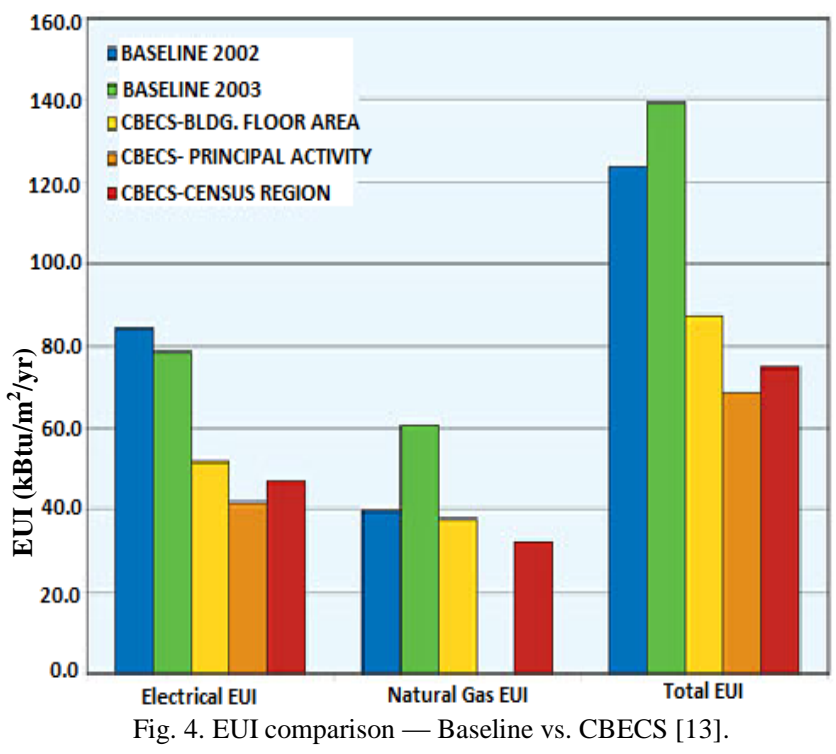

\section{TURKEY APPLICATIONS}

Regulation related increasing energy resources and efficiency in energy usage was released on 2007 at official gazette in Turkey. However, there is not a national CBECS type detailed database, yet. There are also related studies in Turkey, too. These are: BEP-TR, BEP-HY, ENVER, SmartSpaces (Saving Energy in Europe's Public Buildings using ICT) Project, Evaluation of Current Situation of Buildings Sector Report by Tülin Keskin (August 2010), TÜİK data related energy consuming [15]-[17].

\section{A. EnVer Portal Database}

EnVer is energy efficiency portal database for energy consuming declarations in accordance with energy efficiency law. EnVer portal is developed by ministry of energy and natural resources. For proceedings, the companies become a member of EnVer portal and fill in the reference energy information form.

hese companies stated below should enter their energy consumption data to EnVer database: Industrial companies that total average yearly energy consumptions of last three years are thousands TEP and more, Public buildings that its total construction area $10000 \mathrm{~m}^{2}$ or total yearly energy consumption 250 TEP and more, Private buildings that total closed construction area $20000 \mathrm{~m}^{2}$ or total yearly energy consumption 500 TEP and more [18].

\section{B. $\quad B E P-H Y \& B E P-T R$}

BEP-TR is developed by the ministry of environment and urbaning

BEP-HY

(Building

Energy

Performance-Calculation Method) is the road map of calculation of yearly energy consumption amounts/per area $\left(\mathrm{m}^{2}\right)$ and related $\mathrm{CO}_{2}$ emissions of the buildings covered by the $\mathrm{BEP}$ regulations.

BEP-TR is internet based software calculating yearly energy consumption amounts/per area $\left(\mathrm{m}^{2}\right)$ and related $\mathrm{CO}_{2}$ emissions of buildings covered by BEP regulations. Energy performance and emission release class of the buildings are obtained according to BEP-HY results. BEP-TR software training videos are available on the related website. BEP-TR produces the suitable energy idendity card of the related building using BEP-HY [19].

\section{CONCLUSIONS}

Energy efficiency in new building construction has become a key target to lower nation-wide energy use. Goals are to estimate life-cycle energy savings, carbon emission reduction, and cost effectiveness of energy efficiency measures in new commercial buildings using an integrated design approach, and estimate implications.

Determining energy consumption of buildings can be used to decrease energy use in new commercial buildings by $20-30 \%$ on average and up to over $40 \%$. Improved efficiencies allow installation of smaller, cheaper HVAC equipment. These improvements not only save money and energy, but reduce a building's carbon footprint by $16 \%$ on average. A cost on carbon emissions from energy use increases the return on energy efficiency investments, making some cost-ineffective projects economically feasible.

\section{REFERENCES}

[1] P. A. Mathew, L. N. Dunn, M. D. Sohn, A. Mercado, C. Custudio, and T. Walter, "Big-data for building energy performance: Lessons from assembling a very large national database of building energy use," Applied Energy, vol. 140, pp. 85-93, Feb. 2015.

[2] J. Kneifel, "Beyond the code: Energy, carbon, and cost savings using conventional technologies," Energy and Buildings, vol. 43, no. 4, pp 951-959, Apr. 2011.

[3] T. Sharp, "Energy benchmarking in commercial office buildings," Oak Ridge National Laboratory, 2004.

[4] J. Kneifel, "Life-cycle carbon and cost analysis of energy efficiency measures in new commercial buildings," Energy and Buildings, vol. 42, no. 3, pp. 333-340, 2010

[5] H.-X. Zhao and F. Magoulès, "A review on the prediction of building energy consumption," Renewable and Sustainable Energy Reviews, vol. 16, no. 6, pp. 3586-3592, 2012.

[6] J. H. Scofield, "Do LEED-certified buildings save energy? Not really...," Energy and Buildings, vol. 41, no. 12, pp. 1386-1390, Dec. 2009.

[7] W. Chung, "Review of building energy-use performance benchmarking methodologies," Applied Energy, vol. 88, no. 5, pp. 1470-1479, May 2011

[8] J. Michaels. Update on the 2012 commercial building energy consumption survey (CBECS). Commercial Buildings Energy Alliances Webinar. [Online]. Available: http://apps1.eere.energy.gov/buildings/publications/pdfs/alliances/20 120410_webinar_cbebs.pdf

[9] J. Michaels, "Commercial buildings energy consumption survey briefing," Administration Interagency Sustainability Working Group (ISWG), 2008

[10] Y. H. Yau and S. Hasbi, "A review of climate change impacts on commercial buildings and their technical services in the tropics," Renewable and Sustainable Energy Reviews, vol. 18, pp. 430-441, Feb. 2013. 
[11] G. R. Newsham, S. Mancini, and B. J. Birt, "Do LEED-certified buildings save energy? Yes, but...," Energy and Buildings, vol. 41, no. 8, pp. 897-905, Aug. 2009

[12] G. A. Boyd, "Estimating the changes in the distribution of energy efficiency in the U.S. automobile assembly industry," Energy Economics, vol. 42, pp. 81-87, 2014.

[13] C. Li, T. Hong, and D. Yan, "An insight into actual energy use and its drivers in high-performance buildings," Applied Energy, vol. 131, pp. 394-410, 2014.

[14] S. H. Lee, T. Hong, M. A. Piette, and S. C. Taylor-Lange, "Energy retrofit analysis toolkits for commercial buildings: A review," Energy, vol. 89, pp. 1087-1100, Sep. 2015.

[15] N. Eskin and H. Turkmen, "Analysis of annual heating and cooling energy requirements for office buildings in different climates in Turkey," Energy and Buildings, vol. 40, pp. 763-773, 2008.

[16] C. D. Şahin, Z. D. Arsan, S. S. Tunçoku, T. Broström, and G. G. Akkurt, "A transdisciplinary approach on the energy efficient retrofitting of a historic building in the Aegean Region of Turkey," Energy and Buildings, vol. 96, pp. 128-139, June 2015.

[17] F. Taşpınar, N. Çelebi, and N. Tutkun, "Forecasting of daily natural gas consumption on regional basis in Turkey using various computational methods," Energy and Buildings, vol. 56, pp. 23-31, Jan. 2013. [18] ENVER portal. [Online]. Available:
http://www.enver.eie.gov.tr/ENVER.portal

[19] M. Kabak, E. Köse, O. Kırılmaz, and S. Burmaoğlu, "A fuzzy multi-criteria decision making approach to assess building energy performance," Energy and Buildings, vol. 72, pp. 382-389, 2014.

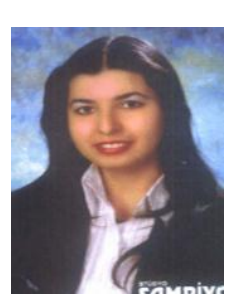

Özlem Boydak was born in Elazıg, Turkey in 1981 She was graduated from both mechanical engineering and electrical engineering from Yildiz Technical University which is one of the best technical universities of Istanbul in Turkey in 2004. She gained her master's degree from the Mechanical Engineering Department of Bogazici University, which is one of the best universities of Turkey. Now, she is a PhD candidate of mechanical engineering at Marmara University in Istanbul and she is the academic staff of Istanbul Medeniyet University as a specialist. She has three international publications previously. Her research interests are energy, energy production cycles, rankine cycle, renewable energy, production of electricity, product development and manufacturing methods. 

Optical, Solar, and Vibration Energy 
